\title{
Microbiological composition associated with vitamin $D$ receptor gene polymorphism in chronic periodontitis
}

\author{
Maria Angélica Toniato Borges(a) \\ Luciene Cristina de Figueiredo ${ }^{(b)}$ \\ Rui Barbosa de Brito Jr(c) \\ Marcelo Faveri(b) \\ Magda Feres $^{(\mathbf{b})}$ \\ (a) $\mathrm{MSC}_{\text {; }}$ (b) PhD - Department of \\ Periodontology, Dental Research Division, \\ Guarulhos University, Guarulhos, SP, Brazil. \\ (c) PhD, Department of Molecular Biology, São \\ Leopoldo Mandic Dental Research Institute, \\ Campinas, SP, Brazil.
}

\begin{abstract}
The aim of this cross-sectional study was to examine the relationship between the composition of the subgingival microbiota and the vitamin D receptor (VDR) gene polymorphism in Brazilian adults with chronic periodontitis. The clinical parameters of probing depth, clinical attachment level, bleeding on probing, plaque accumulation and suppuration were measured in 60 Caucasian adults who were divided into two groups: 30 healthy individuals (control) and 30 with chronic periodontitis (ChP). Subgingival plaque samples were collected from 6 sites per subject and analyzed for 38 bacterial species using the Checkerboard DNA-DNA Hybridization. DNA was obtained from the subjects' epithelial cells by scraping the buccal mucosa and using a mouthwash containing $3 \%$ of glucose. Polymorphism in the VDR gene was analyzed by the polymerase chain reaction (PCR), followed by Taql digestion (RFLP). The healthy subjects presented significantly lower levels $\left(0.3 \times 10^{7} \pm 0.7 \times 10^{7}\right)$ of total microbial counts in comparison with subjects with chronic periodontitis $\left(4.5 \times 10^{7} \pm 2.9 \times 10^{7}\right)$. Regarding the occurrence of VDR polymorphism, it was observed that the Tt genotype was more prevalent in the Periodontitis group (60\%) than in the Healthy group (30\%), while the prevalences of the TT genotype were $23.3 \%$ and $53.3 \%$, respectively (Chi-square test, $\mathrm{p}<0.05$ ). No difference was found in the composition of subgingival microbiota among the VDR genotypes evaluated for the Healthy and Periodontitis groups. In conclusion, the Tt genotype was associated with periodontal disease; however, no association with the subgingival microbiota was observed.
\end{abstract}

Descriptors: Microbiology; Genetic polymorphism; Molecular biology; Vitamin D.

\author{
Corresponding author: \\ Magda Feres \\ Universidade Guarulhos \\ Rua Dr. Nilo Peçanha, 81, Prédio U, \\ $6^{\circ}$ Andar \\ Guarulhos - SP - Brazil \\ CEP: 07011-040 \\ E-mail:mferes@ung.br
}




\section{Introduction}

Periodontitis is an infectious disease of the periodontium in which the presence of specific bacteria is required for disease initiation and progression. ${ }^{1} \mathrm{~A}$ number of factors have been suggested as playing a role in governing the microbial composition of subgingival plaque at a site including environmental and genetic factors. Subject-to-subject differences in the microbial profiles of subgingival plaque samples may indicate that differences in the genetic background of the host may influence the composition of the subgingival microbiota. However, the effects of the genotype of an individual on the composition of subgingival microbiota have been difficult to demonstrate. ${ }^{2}$

Recently, many studies have evaluated potential gene polymorphisms that could influence the oral microbiota of subjects with periodontal diseases. ${ }^{2-}$ 7 Since progressive bone loss is the ultimate result of periodontal disease, some association studies involving the vitamin D receptor (VDR), ${ }^{8-17}$ mostly evaluating the association between the TaqI polymorphism and periodontal disease, have been conducted in different populations. Vitamin D has special roles in regulating the metabolisms of calcium and phosphorus, and in the immunosystem. The biologic function of vitamin $\mathrm{D}$ must be associated with its receptor. ${ }^{10,11}$ At the moment, the association between VDR polymorphism and the risk of periodontal disease has not been confirmed. To our knowledge, only one investigation studied the association between VDR polymorphism and oral microbiota, but only three bacteria species were analyzed (Aggregatibacter actinomycetemcomitans, Porphyromonas gingivalis and Tannerella forsythensis) by culture and their identities confirmed by the polymerase chain reaction in persons with generalized aggressive periodontitis. ${ }^{6}$

Thus, the purpose of the present investigation was to examine the relationship between the composition of subgingival microbiota and the vitamin D receptor gene polymorphism, designed by the TaqI, in Brazilian adults with chronic periodontitis.

\section{Material and Methods Subject population}

Sixty Caucasian subjects were selected for two clinical groups: Chronic periodontitis - ChP $(\mathrm{n}=30)$ and periodontally healthy - Control $(\mathrm{n}=30)$. The patients were selected from the population referred to the periodontal clinic, Guarulhos University (Guarulhos, SP, Brazil). The sample size calculation determined that 30 subjects per group would provide an $80 \%$ power to detect a true difference between the $\mathrm{ChP}$ and control groups using the mean proportion of red complex as the primary outcome variable. A complete periodontal examination was performed, including taking the medical and dental history, an intra-oral examination and full-mouth periodontal probing. Periodontal diagnosis was made, and the subjects who fulfilled the inclusion/ exclusion criteria were invited to participate in the study. If accepted, they were informed of the nature of study participation and their written consent was obtained. The study was approved by the Institutional Committee of Ethics in Clinical Research, Guarulhos University.

\section{Inclusion and exclusion criteria}

Subjects with ChP were $>30$ years old and exhibited at least 6 sites with pocket depth and clinical attachment level measurements $\geq 5 \mathrm{~mm}$. These sites should be located in different teeth and distributed among the four quadrants. The periodontally healthy subjects were at least 30 years old, had no pocket depth or clinical attachment level measurements $>3 \mathrm{~mm}$ and had $<10 \%$ sites exhibiting gingival redness. All subjects had at least 15 natural teeth excluding $3^{\text {rd }}$ molars. The inclusion criteria were based on Armitage ${ }^{18}$ (1999).

Exclusion criteria included previous periodontal therapy, pregnancy, nursing, smoking, any systemic condition that could affect the progression of periodontal disease or that required antibiotic coverage for routine dental therapy and antibiotic therapy in the previous 6 months.

\section{Clinical evaluation}

The clinical evaluation was performed by one trained and calibrated examiner according to Araujo et al. ${ }^{19}$ (2003). Clinical parameters such as presence (score 1 ) or absence (score 0 ) of plaque accumulation, gingival bleeding, bleeding on probing, suppuration 
and measures of pocket depth (PD, mm) and clinical attachment level (CAL, mm) were determined at the baseline visit at 6 sites per tooth (mesiobuccal, buccal, distobuccal, distolingual, lingual and mesiolingual) in all teeth excluding the third molars. PD and CAL measurements were recorded to the nearest millimeter using a North Carolina periodontal probe (Hu-Friedy, Chicago, IL, USA).

\section{Microbiological assessment}

Sample collection

Subgingival plaque samples were collected from six non-contiguous interproximal sites per subject. Sites with PD and CAL $\geq 5 \mathrm{~mm}$ in the ChP group and sites with $\mathrm{PD}<3 \mathrm{~mm}$ in the control group were collected. The selected sites were randomized in different quadrants. After the clinical parameters had been recorded, the supragingival plaque was removed and the samples were taken with individual sterile Gracey curettes and immediately placed in separate Eppendorf tubes containing $0.15 \mathrm{ml}$ TE (10 mM Tris-HCl, $1 \mathrm{mM}$ EDTA, pH 7.6). $0.10 \mathrm{ml}$ of $0.5 \mathrm{M} \mathrm{NaOH}$ was added to each tube and the samples were dispersed using a vortex mixer.

\section{Checkerboard DNA-DNA hybridization}

Counts of 38 bacterial species were determined in each sample, using the Checkerboard DNA-DNA hybridization technique ${ }^{1}$ as previously described by Faveri et al. ${ }^{20}$ (2006). The assay sensitivity was adjusted to permit detection of $10^{4}$ cells of a given species by adjusting the concentration of each DNA probe.

\section{Determination of VDR genotype}

\section{Sample collection and DNA extraction}

Cells were obtained through mouthwash with $3 \%$ glucose solution and scrapings of the buccal mucosa with a sterile wood spatula. DNA was extracted from buccal epithelial cells with sequential phenol/chloroform..$^{21,22}$

\section{Analysis of VDR-Taql site polymorphism}

A VDR region of $340 \mathrm{pb}$ was amplified by the polymerase chain reaction (PCR) utilizing specific oligonucleotide primers (F-5' CAG AGC ATG GAC
AGG GAG CAA G 3' and exon 9 R-5' GGA TGT ACG TCT GCA GTG TG 3'). ${ }^{10}$ Reaction conditions and cycling parameters were set as previously described by Brito Jr. et al. ${ }^{9}$ (2004) and the resulting fragments were separated by $10 \%$ polyacrylamide gel electrophoresis. The gel was stained by the rapid silver staining method. ${ }^{23}$ The restriction fragment length polymorphism is formed by a single base transition $(\mathrm{T} \rightarrow \mathrm{C})$ at codon 352 in exon 9 of the VDR gene that creates a TaqI restriction site. The alleles that result from this change are designated $t$ (TaqI site present, with two fragments: $260 \mathrm{bp}$ and $80 \mathrm{bp}$ ) or T (TaqI site absent: $340 \mathrm{bp}$ ).

\section{Data analysis}

The clinical and microbiological data were analyzed by the Mann-Whitney U Test. The significance of the differences in the observed frequencies of each polymorphism in the control and ChP groups was assessed by the Chi-square test $\left(\chi^{2}\right)$. The risk associated with individual alleles or genotypes was calculated as the odds ratio with $95 \%$ confidence intervals (CI). Differences were considered significant when $\mathrm{p}<0.05$.

\section{Results}

The clinical and demographic characteristics of the patients are presented in Table 1 . The ChP group displayed significantly higher means $(\mathrm{p}<0.05)$ for

Table 1 - Baseline clinical and demographic parameters of the subject population.

\begin{tabular}{|c|c|c|}
\hline & \multicolumn{2}{|c|}{ Mean \pm SD } \\
\hline & $\begin{array}{l}\text { Control } \\
N=30\end{array}$ & $\begin{array}{c}\text { Chronic } \\
\text { periodontitis } \\
N=30\end{array}$ \\
\hline Age (years) & $41.10 \pm 8.5$ & $42.03 \pm 6.2$ \\
\hline Gender (male:female) & $6: 24$ & $8: 22$ \\
\hline Mean pocket depth $(\mathrm{mm})^{*}$ & $2.16 \pm 0.2$ & $3.85 \pm 0.7$ \\
\hline Mean attachment level $(\mathrm{mm})^{*}$ & $2.20 \pm 0.2$ & $4.33 \pm 1.0$ \\
\hline \multicolumn{3}{|l|}{$\%$ sites with: } \\
\hline Plaque* & $43.74 \pm 17.8$ & $84.73 \pm 10.7$ \\
\hline Gingival bleeding* & $6.52 \pm 5.5$ & $40.72 \pm 22.4$ \\
\hline Bleeding on probing* & $27.73 \pm 20.5$ & $63.63 \pm 20.2$ \\
\hline Suppuration* & 0.0 & $3.09 \pm 3.7$ \\
\hline
\end{tabular}


Table 2 - Distribution of the VDR Single Nucleotide Polymorphism (SNP) Taql alleles and genotypes in the control and periodontitis groups.

\begin{tabular}{|c|c|c|c|c|}
\hline SNP & $\begin{array}{l}\text { Control } \\
N(\%)\end{array}$ & $\begin{array}{c}\text { Chronic } \\
\text { periodontitis } \\
\mathrm{N}(\%)\end{array}$ & $\begin{array}{c}\text { Chi-square } \\
\chi^{2}\end{array}$ & $\begin{array}{c}\text { Odds Ratio } \\
\text { OR }\end{array}$ \\
\hline Allele & $60(100)$ & $60(100)$ & & \\
\hline$T$ & $41 \quad(68.3)$ & 32 (53.3) & $\chi^{2}=1.74$ & \\
\hline$t$ & $19 \quad(31.7)$ & $28 \quad(46.7)$ & $p=0.258$ & \\
\hline Genotype & $30(100)$ & $30(100)$ & & TT vs Tt \\
\hline TT & $16 \quad(53.3)$ & $7 \quad(23.3)$ & $\chi^{2}=6.52$ & $\mathrm{OR}=4.57$ \\
\hline $\mathrm{Tt}$ & $9 \quad(30.0)$ & $18 \quad(60.0)$ & $p=0.038$ & $p=0.023$ \\
\hline $\mathrm{H}$ & $5 \quad(16.7)$ & $5 \quad(16.7)$ & & $\mathrm{Cl} 95 \%, 1.4 \leq \mu \geq 15.1$ \\
\hline
\end{tabular}

all the clinical measurements compared with the control group.

The frequencies of the alleles and genotypes are presented in Table 2 . While analyzing alleles and genotypes, a significant difference between the control and ChP groups was found for the VDR TaqI genotype $(\mathrm{p}=0.038)$. Calculating the odds ratio (OR), it was revealed that the individuals with the $\mathrm{Tt}$ genotype were 4.57 times more susceptible to periodontal disease. The genotype distributions were consistent with the assumption of the Hardy-Weinberg equilibrium in the control group. There was no statistical difference in the distribution of the allelic $(\mathrm{T}, \mathrm{t})$ frequencies between the $\mathrm{ChP}$ and healthy control groups ( $\mathrm{p}>0.05)$.

No statistically significant differences were observed in the percentage of DNA probe counts among the genotypes TT, Tt and tt in the healthy and chronic periodontitis groups (Graph 1). Additionally, the proportions of the different complexes did not differ among the genotype groups. For example, the pathogenic species (red and orange complexes) represented $67.1 \%, 65.9 \%$ and $59.9 \%$ of the total microbiota taken from the chronic periodontitis group in the TT, Tt and tt genotypes, respectively; and $24.6 \%, 31.2 \%$ and $29.4 \%$ of the total microbiota taken from healthy subjects (data not presented).

\section{Discussion}

The hypothesis that host genotype may affect the colonization pattern of subgingival species has been extensively discussed in the past few years. The difficulty in confirming or refuting this association is related to two major points. The first one is the lack of specific host genetic factors that are likely to affect the subgingival microbiota and the second point is the difficulty in comprehensively examining the subgingival microbiota. This last impediment was overcome by the development of more rapid microbiological techniques such as checkerboard DNA-DNA hybridization. ${ }^{1}$ Thus, the purpose of the present investigation was to examine the relationship between the composition of subgingival microbiota and the vitamin $\mathrm{D}$ receptor gene polymorphism, designed by the TaqI, in Brazilian adults with chronic periodontitis. It is worth mentioning that the Brazilian population is highly heterogeneous, with Native American, African, and European ancestry. Europeans are the predominant ancestry in the Brazilian southern region, ${ }^{25}$ and that fact was consistent with the occurrence of Caucasoid individuals in our sample.

Several studies have identified clinical evidence that subjects who are carriers of a specific IL-1 gene polymorphism have significantly higher counts of bacteria linked to chronic periodontitis ${ }^{2-5}$ or aggressive periodontitis. ${ }^{12}$ However, considering the VDR gene polymorphism, the data of the present investigation are in accordance with the findings of $\mathrm{Ni}$ bali et al. ${ }^{6}$ (2007), who did not support the notion that differences in host VDR genotype influence the composition of subgingival microbiota.

In the periodontal literature, VDR gene polymorphism was reported to be associated with the incidence of early-onset periodontitis, ${ }^{14,15,17}$ localized early-onset periodontitis ${ }^{10}$ and generalized aggressive periodontitis. ${ }^{13}$

In this study, we found a significant association between the TaqI polymorphism in the VDR gene and the incidence of ChP. The Tt genotype was found to be associated with periodontitis. These data for a 


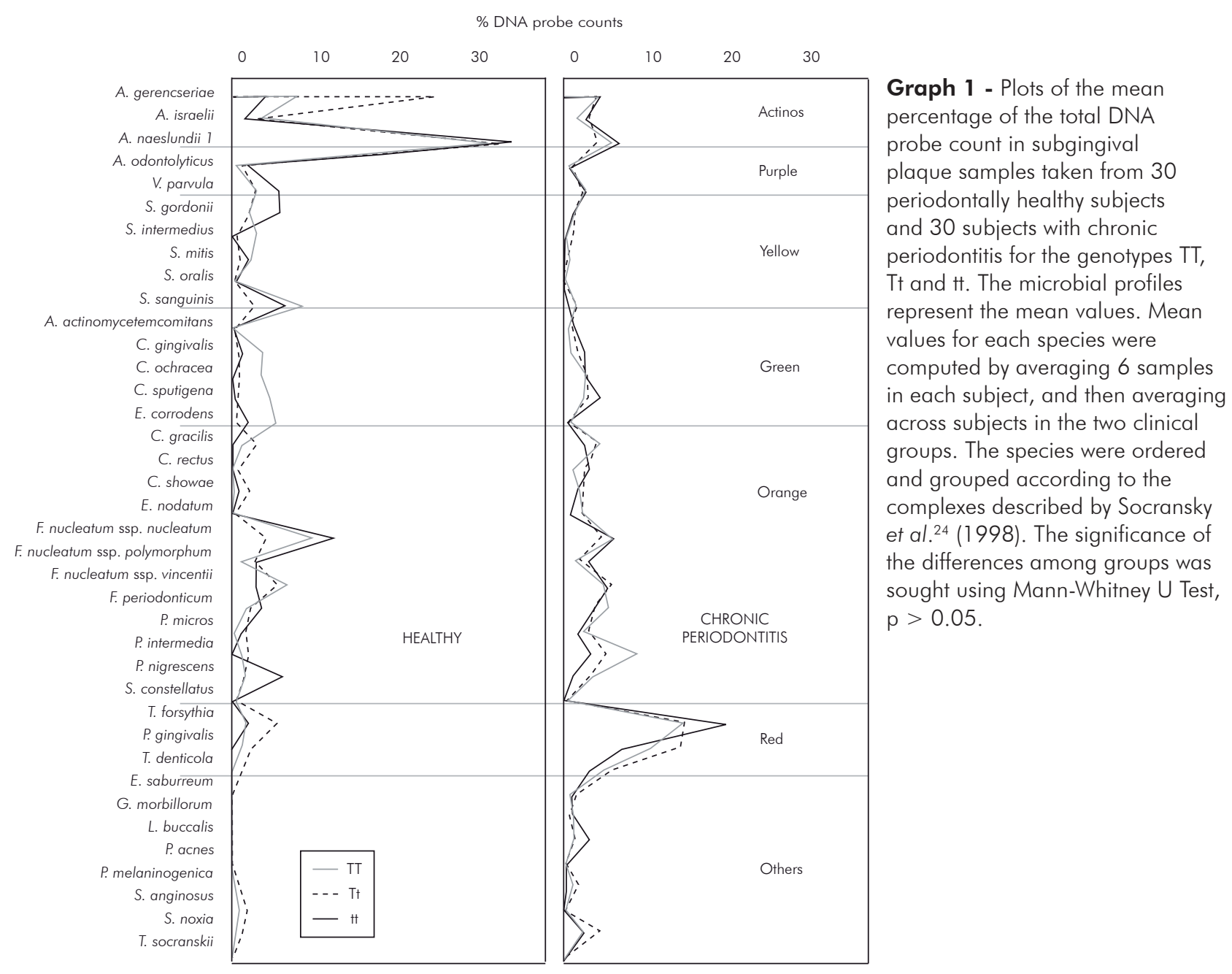

group of chronic periodontal disease versus healthy individuals were similar to the findings presented by Brito Jr et al. ${ }^{9}$ (2004). Those authors were the first to demonstrate an association between VDR gene polymorphism and ChP in the Brazilian population.

Our findings were contradicted by other studies that analyzed the TaqI polymorphism in the VDR gene in different populations. The results of these studies showed an association between ChP and genotype TT or the allele T. ${ }^{15,16}$ Racial differences and the limitations of a small sample size in our study might be the main reason for these different results. Additionally, there is still no definitive conclusion about the functional mechanism of the TaqI VDR gene, and, therefore, more studies are needed to address these aspects.

\section{Conclusion}

In conclusion, the $\mathrm{Tt}$ genotype was associated with periodontal disease; however, no association with the subgingival microbiota was observed.

2. Socransky SS, Haffajee AD, Smith C, Duff GW. Microbiological parameters associated with IL-1 gene polymorphisms in 
periodontitis patients. J Clin Periodontol. 2000;27(11):8108 .

3. Agerbaek MR, Lang NP, Persson R. Microbiological composition associated with interleukin-1 gene polymorphism in subjects undergoing supportive periodontal therapy. J Periodontol. 2006;77(8):1397-402.

4. Kowaslki J, Górska R, Dragan M, Kozak I. Clinical state of the patients with periodontitis, IL-1 polymorphism and pathogens in periodontal pocket - is there a link? (An introductory report). Adv Med Sci. 2006;51 Suppl 1:9-12.

5. Laine ML, Farré MA, García-González MA, van Dijk LJ, Ham AJ, Winkel EG et al. Polymorphisms of the Interleukin-1 gene family, oral microbial pathogens, and smoking in adult periodontitis. J Dent Res. 2001;80(8):1695-9.

6. Nibali L, Ready DR, Parkar M, Brett PM, Wilson M, Tonetti MS et al. Gene polymorphisms and the prevalence of key periodontal pathogens. J Dent Res. 2007;86(5):416-20.

7. Trevilatto PC, Tramontina VA, Machado MAN, Gonçalves RB, Sallum AW, Line SRP. Clinical, genetic and microbiological findings in a Brazilian family with aggressive periodontitis. J Clin Periodontol. 2002;29(3):233-9.

8. Brett PM, Zygogianni P, Griffiths GS, Tomaz M, Parkar M, D'Aiuto $\mathrm{F}$ et al. Functional gene polymorphisms in aggressive and chronic periodontitis. J Dent Res. 2005;84(12):114953.

9. Brito Jr RB, Scarel-Caminaga RM, Trevilatto PC, Souza AP, Barros SP. Polymorphisms in the vitamin D receptor gene are associated with periodontal disease. J Periodontol. 2004;75(8):1090-5.

10. Hennig BJW, Parkhill JM, Chapple ILC, Heasman PA, Taylor JJ. Association of vitamin D receptor gene polymorphism with localized early-onset periodontal diseases. J Periodontol. 1999;70(9):1032-8.

11. Inagaki K, Krall EA, Fleet JC, Garcia RI. Vitamin D receptor alleles, periodontal disease progression, and tooth loss in the VA Dental Longitudinal Study. J Periodontol. 2003;74(2):1617.

12. Naito M, Miyaki K, Naito T, Zhang L, Hoshi K, Hara A et al. Association between vitamin $\mathrm{D}$ receptor gene haplotypes and chronic periodontitis among Japanese men. Int J Med Sci. 2007;4(4):216-22.

13. Park KS, Nam JH, Choi J. The short vitamin D receptor is associated with increased risk for generalized aggressive periodontitis. J Clin Periodontol. 2006;33(8):524-8.
14. Sun JL, Meng HX, Cao CF, Tachi Y, Shinohara M, Ueda M et al. Relationship between vitamin $\mathrm{D}$ receptor gene polymorphism and periodontitis. J Periodontal Res. 2002;37(4):2637.

15. Tachi Y, Shimpuku H, Nosaka Y, Kawamura T, Shinohara M, Ueda $\mathrm{M}$ et al. Association of vitamin $\mathrm{D}$ receptor gene polymorphism with periodontal diseases in Japanese and Chinese. Nucleic Acids Res Suppl. 2001;(1):111-2.

16. Tachi Y, Shimpuku H, Nosaka Y, Kawamura T, Shinohara M, Ueda $\mathrm{M}$ et al. Vitamin D receptor gene polymorphism is associated with chronic periodontitis. Life Sci. 2003;73(26):331321.

17. Yoshihara A, Sugita N, Yamamoto K, Kobayashi T, Miyazaki $\mathrm{H}$, Yoshi H. Analysis of vitamin D and FCgamma receptor polymorphisms in Japanese patients with generalized earlyonset periodontitis. J Dent Res. 2001;80(12):2051-4.

18. Armitage GC. Development of a classification system for periodontal diseases and conditions. Ann Periodontol. 1999;4(1):1-6.

19. Araujo MW, Hovey KM, Benedek JR, Grossi SG, Dorn J, Wactawshi-Wende J et al. Reproducibility of probing depth measurement using a constant-force electronic probe: analysis of inter- and intraexaminer variability. J Periodontol. 2003;74(12):1736-40.

20. Faveri M, Feres M, Shibli JA, Hayacibara RF, Hayacibara MM, de Figueiredo LC. Microbiota of the dorsum of the tongue after plaque accumulation: an experimental study in humans. J Periodontol. 2006;77(9):1539-46.

21. Haussler MR, Whitfied GK, Haussler CA, Hsieh JC, Thompson PD, Selznick SH et al. The nuclear vitamin D receptor: biological and molecular regulatory properties revealed. J Bone Miner Res. 1998;13(3):325-49.

22. Trevilatto PC, Line SRP. Use of buccal epithelial cells for PCR amplification of large DNA fragment. J Forensic Odontostomatol. 2000;18(1):6-9.

23. Sanguinetti CJ, Dias Neto E, Simpson AJG. Rapid silver staining and recovery of PCR products separated on polyacrylamide gels. Biotechniques. 1994;17(5):914-21.

24. Socransky SS, Haffajee AD, Cugini MA, Smith C, Kent RL Jr. Microbial complexes in subgingival plaque. J Clin Periodontol. 1998;25(2):134-44.

25. Instituto Brasileiro de Geografia e Estatística (IBGE). Os imigrantes alemães no Brasil, 2004. Available at: http://www.ibge. gov.br/ibgeteen/povoamento/alemaes/imigalema.html. 